dealt with Dr. J.S. Wallace's "The Rôle of Modern Dietetics in the Causation of Disease" and from it (p. 458, D.S., June $3 \mathrm{rd}, 1905$ ) is taken the following passage : "Dr. Wallace has, we must point out, fallen into one error. He seems to think that the value of the use of hard and resistant food and general exercise of the jaw muscles as prophylactics against dental caries is a new discovery. We do not agree with him, and for this reason. 'Coleman's Manual of Dentai Surgery and Pathology,' published as far back as 1881, contains on pp. 103, 104 an exhaustive argument on this very point. It is thereon pointed out what changes, both in character and preparation, the food of man has undergone during the last few centuries. The differences in his bread, meat, cooking, and manner of devouring his food are fully pointed out, special stress being laid upon the fact that since the introduction of the knife and fork the incisors and cuspidati by which in former ages the meat was torn from the bone have had their office converted into almost a sinecure."

In anticipation of your courtesy,

I am, with thanks,

Nor. 23rd, 1908.

THE EDitor OF THE "Dental SuRgeon."

\section{THE ELECTROLYTIC ADMINISTRATION OF DRUGS.}

To the Editor of THE LANCET.

SIR,-I would like to point out that cataphoric medication is not only not new to medicine but that it has been used also in dental surgery for many years (personally for 21 years). 11 years ago I wrote ${ }^{1}$ describing the modus operand $i$ for dissipating periodontitis, alveolar abscess, for obtunding sensitive dentine, and for bleaching discoloured teeth by cataphoresis. In ancther journal ${ }^{2}$ I described about 30 cases where I had inter alia so obtunded the dentine that it could be drilled for the purpose of "filling" without the slightest pain or else anæesthetised the pulp that it could be extracted without the patient suffering any discomfort. I was therefore somewhat amused when the "Diurnal Reflector" heralded forth cataphoresis as another of its great medical diseoveries, especially as the process is probably older than most of us living.

$$
\text { I am, Sir, yours faithfully, }
$$

H. Fielden BRrgGs, M.D. Brux., L.A.H. Dub., L.D.S. Glasg., D.D.S. Univ. Mich.

Eastbourne, Nov. 20th, 1908.

\section{EPSOM COLLEGE: LATE ARCHDEACON THORNTON MEMORIAL FUND.}

\section{Io the Editor of THE LANCET.}

SiR,-May I be permitted through your columns to thank the very numerous Old Epsomians of the late headmaster's time (1855 to 1870), so large a proportion of whom are in the medical profession, for their generous donations to this fund, and also to inform them that it has been decided to place a very beautiful stained-glass window in the College chapel as the most fitting memorial to so esteemed a man. The window will be unveiled next Founders' Day and all subscribers will in due course receive notice of, and an invitation to, the ceremonial.

I am, Sir, yours faithfully,

Lonỏon, W.C., Nov. 24th, 1908.

Percival TuRner, Honorary Secretary.

UNUSUAL FOREIGN BODY IN THE EAR. To the Editor of THE LANCET.

SIR,-The following interesting case came to my consulting-room this week. There is nothing particular about it clinically but the circumstances are certainly very unusual. The patient, a prominent volunteer, came to me complaining of deafness. His account of his case was as follows. He had just purchased some artificial ear drums, and on inserting one he became very deaf indeed; on withdrawing the instrument the deafness remained the same. He was the victim of suppurating ears and as a consequence somewhat hard of hearing and

1 The Medical Annual, 1897, p. 187 et seq. 2 The Dental Record, April, 1897. hence the attempt to use the artificial drum. This great increase of deafness after using the artificial drum brought him to me. On examining his ear I found deep in the canal a pultaceous mass of pus and débris and a black-looking body. On removing this with the forceps it proved to be a large earwig. The patient then told me that last August, being at camp, during one night he was awakened by fearful humming and buzzing in the ear. Energetically with his little finger he endeavoured to stop it and finally succeeded; he felt sure that the insect had dropped out, and thought no more about it. It seems strange that this large insect could remain in an ear, and that a suppurating one, for three months without causing more disturbance. How long it would have remained without notice had the patient not attempted to use the artificial drum one can only speculate. It is somewhat singular that whilst in the public mind this insect is so closely associated with the ear one should so seldom find any actual cases.

I am, Sir, yours faithfully, JoHN Foster, F.R.C.S. Edin.

Ophthalmic and Aural Surgeon, Cameron and Hartlepools West Hartlepool, Nov. 19th, 1908. Hospitals.

\section{PURE SODA-WATER.}

\section{To the Editor of THE LANCET.}

SIR, - With reference to your extract in THE LANCET of Nov. 14th from the report of Dr. W. Collingridge, medical officer of health of the City of London, concerning impurities in soda-water, I should be glad to point out in your columns, with your permission, that the fault is not so much that of the soda-water manufacturers themselves as that of the public who place, or allow to be placed, the empty bottles in any convenient corner, regardless of the fact that these empty bottles will afterwards be collected, sent back to the mineral water manufacturers, and by them refilled, after washing in a manner which is not always effective. The microbes discovered upon analysis by Dr. E. E. Klein, bacteriologist to the City council-viz.: (a) "cocci" ; (b) "sporing bacilli"; and (c) "small Gram-positive nonmobile bacilli, which in shape resembled diphtheroid microbes"-prove, although they gave no Neisser staining or caused any change in a guinea-pig's subcutaneous tissue when injected in large doses, that some of the empty bottles collected must have been deposited, somewhere and for some time, amidst garbage such as anyone with the most elementary knowledge of hygienic principles would seriously avoid. I would like to add that personally I prefer to purchase from a chemist liquid carbonic acid gas in small steel bulbs and then to aerate by this means boiled water in a special syphon provided for the purpose which I also obtained from my chemist. As the syphon is my property, remains in my home, and can be cleaned as often as considered necessary, I feel secure from the ravages of diphtheria, at least from this source.

Nov. 18th, 1908.

I am, Sir, yours faithfully,

\section{DEATH CERTIFICATION AND MEDICAL SECRECY.}

To the Editor of THE LANCET.

SIR,-I understand that the Brussels Medical Practitioners' College having pointed out to the communal council of that city that the form of death certificate supplied for the cause of death to be filled in by the medical attendant having to be handed open to the family of the deceased obliges the medical man to violate his obligation of professional secrecy, a promise has been given by the director of the sanitary service of the city that a new form for a "confidential medical certificate" shall be supplied. This will be handed, sealed, to the family, and after having been utilised for registration and statistical purposes (for which the name of the deceased is not required) it will be burnt. Thus there will be no permanent record of the cause of death. Surely this, though a most desirable change from the open certificate, which is necessarily sometimes so partial a statement of trath that it is practically false, is carrying medical secrecy to a dangerous length. There are many criminal trials where the certificate of the cause of death plays a very important part and it would surely be as easy to devise a system by 